\title{
A semi-quantitative assay to screen for angiogenic compounds and compounds with angiogenic potential using the EA.hy926 endothelial cell line
}

\author{
EVELYN ARANDA \& GARETH I. OWEN
}

Departamento de Ciencias Fisiológicas, Facultad de Ciencias Biológicas, Pontificia Universidad Católica de Chile, Alameda 340, Santiago, Chile.

\begin{abstract}
Angiogenesis, the development of new capillary vessels, has a host of clinical manifestations. The identification of agents that increase or decrease angiogenesis is of great pharmaceutical interest. Classically, in vitro angiogenesis utilizes human umbilical vein endothelial cells (HUVEC) grown in matrigel. This valid and simple method has the drawbacks that each cell population is distinct and the constraint of obtaining primary source material. Herein we utilize the established EA.hy926 endothelial cell line as our model for in vitro angiogenesis and present a novel formula to quantify endothelial cell remodeling to identify pro- and anti-angiogenic agents. Furthermore, our technique details the procedures to identify and quantify compounds that have the capacity to generate pro- or anti-angiogenic factors when given to non-endothelial cells, which we define herein as angiogenic potential. In conclusion, we propose a novel formula that we are confident accurately reflects the degree of in vitro angiogenesis allowing the quantification of prospective angiogenic compounds.
\end{abstract}

Key terms: angiogenesis, EA.hy926, HUVEC, endothelial, formula, in vitro assay, matrigel.

The abbreviations used are: CM: Conditioned medium; VEGF: Vascular endothelial growth factor; EGF: Epidermal growth factor; HUVEC: Human umbilical vein endothelial cells; FBS: Fetal bovine serum; FVIIa: Factor VII activated; IMDM: Iscove's Modified Dulbecco's Medium; DMEM: Dulbecco's Modified Eagle's Medium

\section{INTRODUCTION}

\section{Angiogenesis}

Angiogenesis is the development of new capillary vessels. The development of proangiogenic and anti-angiogenic drugs has the potential to deliver novel and effective therapy directly targeting angiogenesisdependent pathologies (Gerstner et al., 2007; Pluda, 1997). Of a host of clinical manifestations that could benefit from antiangiogenic therapy are cancer, inflammatory disorders, diabetic blindness, age-related muscular degeneration, psoriasis, cardiovascular and autoimmune diseases, among many others. Clinical presentations that could benefit from proangiogenesis drugs are coronary artery disease, stroke and delayed wound healing. In cancer, the survival and subsequent metastasis of solid tumors appears to be dependent on neovascularization of the primary tumor, ensuring an adequate supply of oxygen and nutrients (Folkman and Shing, 1992).

Correspondence and reprint requests should be sent to: Gareth I. Owen. Departamento de Ciencias Fisiológicas, Facultad de Ciencias Biológicas, Pontificia Universidad Católica de Chile, Alameda 340, Santiago, Chile. Tel: (56) 2-686 2854; Fax: (56) 2-222 5515; Email: gowen@bio.puc.cl

Received: April 9, 2009. In Revised form: July 15, 2009. Accepted: July 30, 2009

This work was supported by grant 1060495 from the Chilean national funding organization FONDECYT. 


\section{The Angiogenesis Assay}

In the first stages of screening for potential pro- or anti-angiogenic compounds a simple in vitro assay is required to give an initial indication of effectiveness and thus lower the requirements for more cumbersome and expensive in vivo animal models. The in vitro assays used to investigate angiogenesis are multiple and work on the simple principal that the formation of capillary-like structures in matrigel (a trade name from BD Biosciences for a gelatinous protein mixture secreted by mouse tumor cells that resembles the complex extracellular environment found in many tissues) extrapolates to angiogenesis (Goodwin, 2007). Assays generally focus on the use of Human Umbilical Vein Endothelial Cells (HUVEC), which are isolated from normal human umbilical vein. Although several private companies currently offer these cells, they are expensive, require testing for pathogens and vary from lot to lot. Generally, scientific laboratories depend on collaborations with local hospitals for the procurement of human umbilical vein and their subsequent isolation and primary cell culture. An alternative in vitro model for angiogenesis was established in 1983 with the creation of EA.hy926 cell line (Edgell et al., 1983, 1990; Bauer et al., 1992).

\section{EA.hy926 cell line}

The establishment of the EA.hy926 endothelial cell line was reported by $\mathrm{Dr}$ Cora-Jean S. Edgell of the University of North Carolina, Chapell Hill, NC, USA. This cell line was obtained by the hybridization of human umbilical vein endothelial cells with the A549/8 human lung carcinoma cell line, yet interestingly for models of angiogenesis in vitro, has maintained the phenotype of endothelial cells. This cell line demonstrates highly differentiated functions that are characteristic of human vascular endothelium, while offering the advantage of immortality, stability through passage number and, as with any cell line, the reproducibility of results (Edgell et al., 1983, 1990). More specifically, Dr Edgell and other investigators have demonstrated that
EA.hy926 cells express endothelin-1, Weibel-Palade bodies, prostacyclin, factor VIII-related antigen, endothelial adhesion molecules ICAM-1 and VCAM-1, as are characteristic of pure endothelial cultured cells (Edgell et al., 1983, 1990; Emeis and Edgell, 1988; Thornhill et al., 1993; Saijonmaa et al., 1991; Van Oost et al., 1986; Suggs et al., 1986). The EA.hy926 cell line has also been reported to be a preferable homogeneous experimental model because it permits more consistent responses to specific variables and greater reproducibility of data (Eremeeva and Silverman, 1998). In 1992, Bauer et al., (1992) showed that EA.hy926 cells are capable of undergoing tube formation when grown on matrigel.

Quantification of an in vitro angiogenesis assay

Endothelial cells of all origins grown on martigel appear able to form tubules spontaneously, as has been demonstrated by the wide range of endothelial cells used in this process (refer to the column "model" in Table II). Thus the matrigel assay of tubule formation has become a useful in vitro assay to observe at least two key steps in the angiogenic pathway; migration and differentiation of endothelial cells. Until recently, the methods to evaluate angiogenesis in vitro were mostly descriptive, i.e. the presence or absence of tube formation or three-dimensional cell organization angiogenesis was reported. However, it soon became clear that certain anti- or pro-angiogenic factors/drugs decreased or increased angiogenesis in vitro more than others, thus creating the requirement for a quantitative assay to measure these differences. The first quantifications used length measurements of tube-like structures as an angiogenic index (Yamagishi et al., 1997). In 1998, Jones et al., counted the number of connected EA.hy926 cells and divided that number by the total number of cells in the same microscopic field. The technique of measuring branching or sprouting, combined with tube length and/or number of connecting tubes has become the most commonly used estimation of angiogenic 
potential using any endothelial cell system reported in the literature. Interestingly, during an exhaustive search of the literature, we found that no common formula was applied and in most cases the method of quantification was not stated. Although, each of these methods gives an indication of angiogenesis in vitro in relation to the compound under analysis, these methods are not suitable to detect small changes. As will be elaborated in greater detail in this paper and in accordance with previous reports in both EA.hy926 cells and HUVEC models, there is a reorganization of endothelial cells once cell-cell contacts have been formed and this organization changes over time. Most importantly for the creation of an angiogenic model, we have observed that this formation of a "complex mesh" occurs in the presence of certain angiogenic factors, but not all. More recent papers have studied branch points and the area covered by tubules (Movafagh et al., 2006; Xu et al., 2008). Guidolin et al, (2004) described an image analysis method based on topological and fractal parameters (refer to table II) to evaluate tube formation. They both suggest dimensional parameters as a measure of the number of formed tubules. In 2006, Lake et al., assigned numeric values based on the quality and number of the tubes. In 2008, Basu et al., (2008), analyzed angiogenesis in vitro with an automated algorithm that identified the tubes formed by association and clustering of endothelial cells. All of these studies provide measurement of different steps of angiogenesis. Herein, we demonstrate the progression of tube formation in matrigel using the EA.hy926 cell line, and present a formula that we believe best integrates each step of this in vitro process to allow quantification and thus deliver the potential to distinguish between two or more compounds or the analysis of the effect of combinations of such compounds. This is accomplished by the assignment of a numeric score to each step of the process from "sprouting", through the formation of "polygons" or "honeycomb patterns" to the formation of "complex meshes". This method and formula we believe gives an accurate numerical value to prospective compounds in a simple, inexpensive and rapid manner, thus facilitating the analysis and interpretation of the results obtained in in vitro angiogenesis assays, both in industry and in the scientific laboratory.

\section{Is a compound "angiogenic" or does it possesses "angiogenic potential”?}

There are two methods commonly used by which compounds are tested for their role in angiogenesis. Firstly, endothelial cells or endothelial derived cell lines are grown on matrigel in the presence of a compound under examination, with the resulting formation or inhibition of capillary-like structures. In this scenario, the compound under investigation can directly stimulate or inhibit the remodeling of endothelial cells. These compounds are referred to as pro- or anti-angiogenic. The second method examines the potential of a compound to stimulate angiogenic or anti-angiogenic factors and is accessed by adding the compound to a separate cell line, primary cell culture or tissue, then after a given period of time deemed sufficient to allow the liberation of angiogenic factors, the medium is collected (now referred to as conditioned medium), incubated with endothelial cells in matrigel and the formation of capillary-like structures is examined. Herein, we have given the name angiogenic potential to the capacity of a compound that, when given to nonendothelial cells, can generate conditioned medium capable of increasing (proangiogenic potential) or decreasing (antiangiogenic potential) the formation of capillary-like structures in cultured endothelial cells or endothelial cell derived cell lines.

\section{MATERIALS AND METHODS}

\section{Tissue culture}

The endothelial cell line EA.hy926 cells was maintained in Iscove's Modified Dulbecco's Medium (IMDM, Invitrogen, NY, USA/Sigma Aldrich) with $10 \%$ fetal bovine serum (FBS) (Invitrogen, NY, USA/ 
Sigma Aldrich ) in the presence of $100 \mathrm{U} /$ $\mathrm{ml}$ penicillin $\mathrm{G}$, and $100 \mathrm{mg} / \mathrm{ml}$ streptomycin sulfate (Invitrogen, NY, USA) at $37^{\circ} \mathrm{C}$ with $5 \% \mathrm{CO}_{2}$.

\section{The angiogenesis assay:}

In this measurement of angiogenesis in vitro, conditioned medium (CM) from cancer cell lines was obtained by incubating subconfluent 60 X $15 \mathrm{~mm}$ tissue culture grade Petri dishes (Falcon, Becton Dickinson, Lincoln Park, NJ) with $2 \mathrm{ml}$ of serum-free (SFM) DMEM F12 (Dulbecco's Modified Eagle's Medium F12). By their nature, cancer cell lines possess basal proangiogenic activity and thus medium taken from these cultured cells will allow a certain degree of endothelial cell reorganization. Higher basal endothelial cell reorganization, preferable with screening potential antiangiogenic compounds, can be achieved by the addition of previously identified proangiogenic factors (pro-angiogenic cocktail). The addition of serum will also raise the basal levels of EA.hy926 endothelial cell reorganization.

For the measurement of angiogenic potential, the compound under examination was added to medium covering cancer cells in culture. After a 24-hour incubation, the medium, now termed CM, was collected in a Falcon tube (Falcon, Becton Dickinson, Lincoln Park, NJ) and centrifuged at 3000 $\mathrm{X} \mathrm{g}$ for 4 minutes to remove cell debris. This CM was then used to resuspend and plate the EA.hy926 cells onto matrigel.

Previously, $0.2 \mathrm{ml}$ of matrigel (BD Biosciences, New Bedford, MA) was dispensed per well into 24-well tissue culture plates (Falcon, Becton Dickinson, Lincoln Park, NJ) using a cold pipette to avoid the formation of bubbles. The matrigel was polymerized for 1 hour at $37^{\circ} \mathrm{C}$ with $5 \% \mathrm{CO}_{2}$. EA.hy926 cells were trypsinized and 40,000 cells were plated onto matrigel in the presence of $\mathrm{CM}$ or compounds under investigation for their pro- or anti-angiogenic activity.

The EA.hy926 cells were observed periodically and photographed using inverted phase contrast photomicroscope with a $20 \mathrm{X}$ objective. 10 representative images per well were recorded and transferred to the computer for image analysis.

\section{Additional Information}

For the purposes of the representative analysis performed in this paper, the ZR75-1 breast cancer cell line (Engel et al., 1978) was maintained in DMEM/F12 media supplemented with 10\% FBS (Invitrogen, NY, USA) in the presence of $100 \mathrm{U} / \mathrm{ml}$ penicillin $\mathrm{G}$, and $100 \mathrm{mg} / \mathrm{ml}$ streptomycin sulfate (Invitrogen, NY, USA) at $37^{\circ} \mathrm{C}$ with $5 \% \mathrm{CO}_{2}$. A pro-angiogenic cocktail, consisting of epidermal growth factor (EGF, at a final concentration of $10 \mathrm{nM}$ in culture medium, Upstate Biotechnology, NY, USA), Factor VIIa (10 nM in culture medium, Sigma-Aldrich, St Louis, USA) and progesterone (a final concentration 10 $\mathrm{nM}$ in ethanol, Sigma-Aldrich, St Louis, USA), was add to the breast cancer cell line 24 hours before the medium was collected. In the presence of this pro-angiogenic cocktail, sprouting began around 1-2 hours and the remodelling was complete at approximately 12 hours. For the purpose of demonstrating anti-angiogenic activity, we utilized the known anti-angiogenic estrogen metabolite 2-methoxyestradiol (2ME, Steroloids, Inc., Wilton, NH, USA) (Mabjeesh et al., 2003; Ricker et al., 2004; Brahn et al., 2008) at concentrations stated in the corresponding figure legends. To demonstrate pro-angiogenic potential, we utilized Factor VIIa at a final concentration of $10 \mathrm{nM}$ in $\mathrm{CM}$ pertaining to ZR-75 cells not treated with the above-mentioned angiogenic cocktail. Statistical analysis was performed by student t-test analysis with significance set at $\mathrm{p}<0.05$. Bars represent \pm SD (standard deviation) of the mean.

\section{Interpretation of Results:}

Although the growth of EA.hy926 in matrigel has been documented, in the following section we report the process in more detail to introduce our terminology and to justify a numerical association at each step. A critical factor is the number of EA.hy926 cells plated onto the area of 
matrigel. Too few cells cannot form networks, while too many cells make counting and the interpretation of results more difficult. When seeded onto matrigel in the presence of appropriate media (serum or factor containing medium or $\mathrm{CM}$ from cultured cells), EA.hy926 starts to reorganize within the first hour. The cells start out as spherical forms (Panel 1, fig. 1), but quickly flatten and begin to show projections. This process is commonly referred to as sprouting (Table I; Panel 2, fig. 1). During this time, cell migration is observed, resulting in closer proximity of the EA.hy926 cells. This is a phenomenon that will continue throughout the process. These sprouts connect with similar projections originating from other cells to form a cell-cell contact, to which we designate the name connected cells (Table I; Panels 3 and 4, fig. 1). This process continues between cells and may involve multiple projections from the same cell to form a series of polygon structures when observed under the microscope (Panel 5-8, fig. 1). This formation of polygon structures has also been referred to by other authors as a "Honeycomb formation" (Dorrel et al., 2002). Based on our studies, we have observed that some tested compounds have the pro-angiogenic potential to reorganize to this stage but go no further. The following stage involves the approximation of cells to form polygon structures that have a wall, which is two to three cells thick (Panel 7, fig. 1). The presence of these structures is given the name complex mesh. This stage demonstrates rapid migration and as a generalization, but not a rule, may involve the loss of numbers of polygon structures. It cannot be ruled out that during this process, in fact during the process as a whole, that cell division is occurring. However, based on our

A.
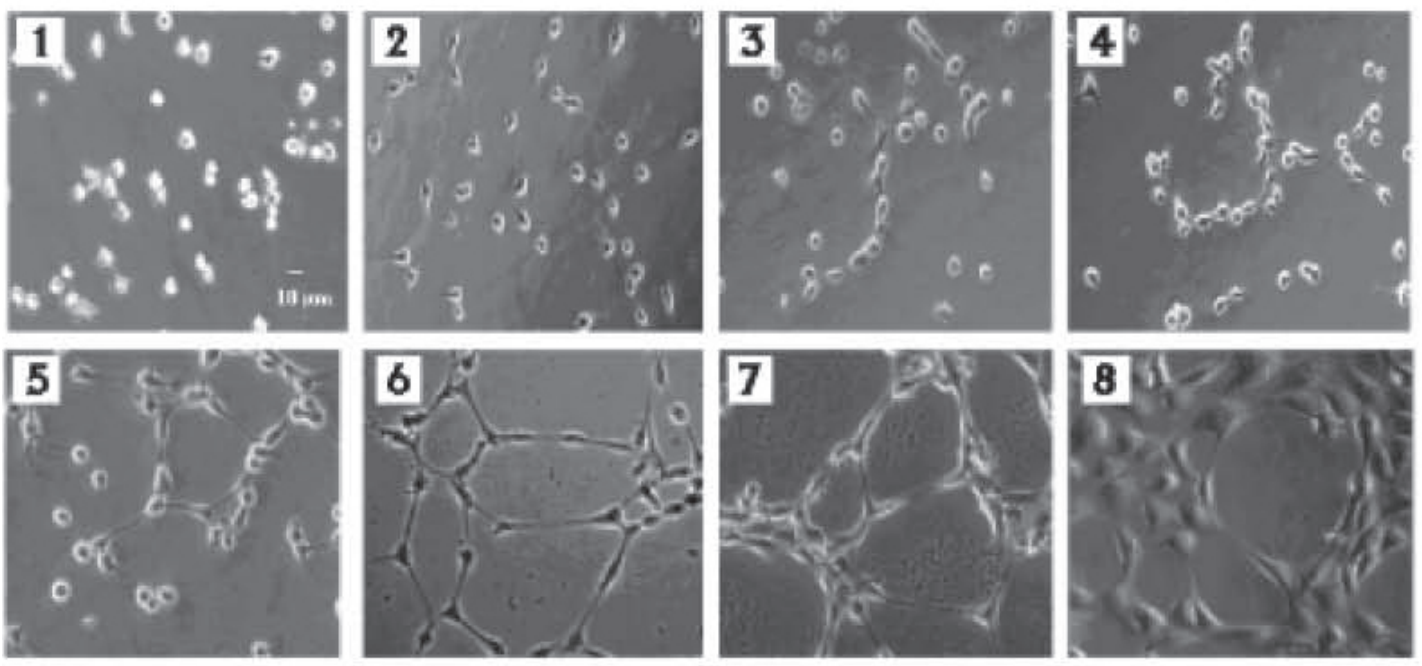

B.

Angiogenic score $=\left[\frac{(\text { No. of sprouting cells }) 1+(\text { No. of connected cells }) 2+(\text { Number of polvgons }) 3}{\text { Total number of cells }}\right]+[0,1$ or 2$]$

Figure 1A: Different steps observed in the in vitro angiogenesis assay. (1) EA.hy926 cells immediately after initial seeding on matrigel, (2) EA.hy926 cells begin to sprout, (3-4) EA.hy926 cells continue elongating and begin to connect. In (5) and (6) EA.hy926 cells form polygon structures. Finally, EA.hy926 cells form complex meshes of 2-3 cells in thickness (7) or more (8).

Figure 1B: Formula for quantification of the angiogenic score. 
experience on counting numerous individual microscopic fields, there is not a major difference in cell number, whether the cells are undergoing tubule formation or not, nor in any individual stage of this process. This point is demonstrated in figure $2 \mathrm{C}$ and $2 \mathrm{D}$, where the standard error represents the fluctuation in cell number in the optic fields for each condition tested. As this complex mesh develops more polygons disappear and are replaced by larger rounded structures with walls four to five cells thick (Panel 8, fig. 1). At least in our experience this state appears to be the extent of EA.hy926 remodeling in matrigel. Prolonged times or the addition of new serum containing medium does not change the form. On the contrary, if the medium is not changed after the first 24 hours, the EA.hy926 start to loss their connections, take on a darker and more rounded appearance indicative of cell death. The timing of this process is arbitrary. Depending on the angiogenic factors used, this entire process can occur within six hours or more than 20 hours. Thus, this assay is open to interpretation depending on the compound being analyzed (and the cells used to obtain $\mathrm{CM}$ ). If the compound is under analysis to test if it has angiogenic properties, the answer is a simple yes or no. If however, two pro- or anti-angiogenic compounds are being examined, differences may need to be interpreted in terms of the

TABLE I

Definitions of terms utilized in angiogenesis assays and introduced in this paper.

\begin{tabular}{|c|c|c|}
\hline Term & Alternative nomenclature & Definition \\
\hline Capillary-like structures & $\begin{array}{l}\text { Tubule or tube formation, tubular } \\
\text { structures cord, cord-like structures, } \\
\text { cable formation, ridges, vessel-like } \\
\text { structure, tubule or tubular branches. }\end{array}$ & $\begin{array}{l}\text { Remodeling of EA.hy } 926 \text { or endothe- } \\
\text { lial cells in matrigel. The general } \\
\text { process of cell elongation and reorga- } \\
\text { nization. }\end{array}$ \\
\hline Polygons & $\begin{array}{l}\text { Honeycomb, Internal holes, Geometric } \\
\text { tubule-like network, angiogenic } \\
\text { structures, Closed rings. }\end{array}$ & Enclosed structures in matrigel. \\
\hline Connected cells & Cells involved in tubular structures & $\begin{array}{l}\text { Two or more cells joined by projectio- } \\
\text { ns or direct cell contact. }\end{array}$ \\
\hline Sprouting & Budding, Branching & $\begin{array}{l}\text { Cellular projections of EA.hy } 926 \text {, } \\
\text { which do not result in contact with } \\
\text { other cells. }\end{array}$ \\
\hline Angiogenic activity & Angiogenic activity & $\begin{array}{l}\text { The ability of a compound(s) to } \\
\text { increase or decrease the ability of } \\
\text { conditioned medium derived from } \\
\text { non-endothelial cells to increase or } \\
\text { decrease endothelial cell capillary-like } \\
\text { structure formation in matrigel }\end{array}$ \\
\hline Angiogenic (pro or anti) & & $\begin{array}{l}\text { The ability of a compound(s) to } \\
\text { increase (pro) or decrease (anti) } \\
\text { capillary-like structure formation in } \\
\text { matrigel when added directly to } \\
\text { medium covering endothelial cells. }\end{array}$ \\
\hline Complex Mesh & $\begin{array}{l}\text { Network, Cluster of cells, Microvessel } \\
\text { formation, Capillary morphogenesis, } \\
\text { Capillary plexus, Tube network, } \\
\text { Anastomotic tubes with multicentric } \\
\text { junctions. }\end{array}$ & $\begin{array}{l}\text { Further reorganization of capillary- } \\
\text { like structures after the formation of } \\
\text { polygons. The polygon structures are } \\
\text { reinforced with more than one layer of } \\
\text { cells in their walls. }\end{array}$ \\
\hline
\end{tabular}


kinetics of the two compounds in their ability to bring about EA.hy 926 remodeling.

To quantify this method of angiogenesis, in vitro cells are periodically removed (we have found that bihourly analysis will suffice) from the incubator, evaluated and photographed if necessary. We have found that 10 photographs per well (per treatment) provides a more than sufficient view of the angiogenic process that is occurring. The selection of these 10 fields/photographs is arbitrary, but in the opinion of the researcher should be the most representative of the well. This approach is favorable over 10 random fields or 10 fixed fields, as cell
A.

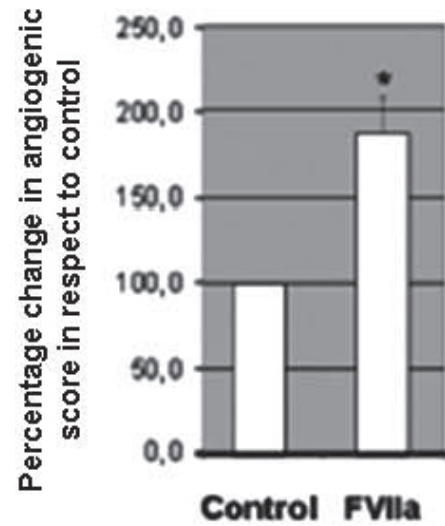

C.

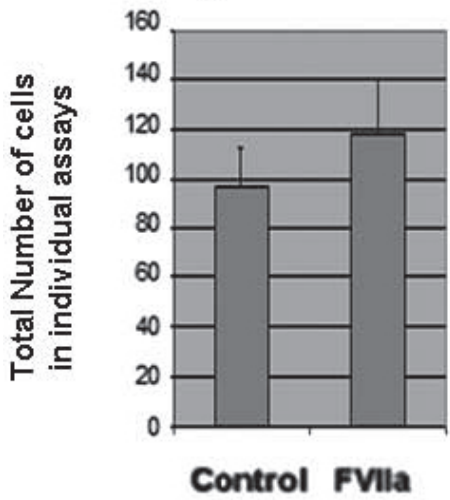

B.

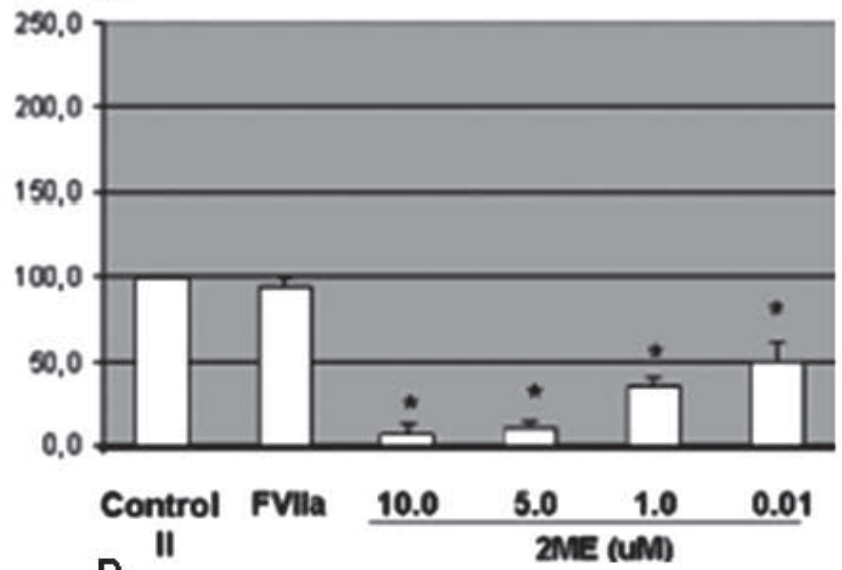

D.

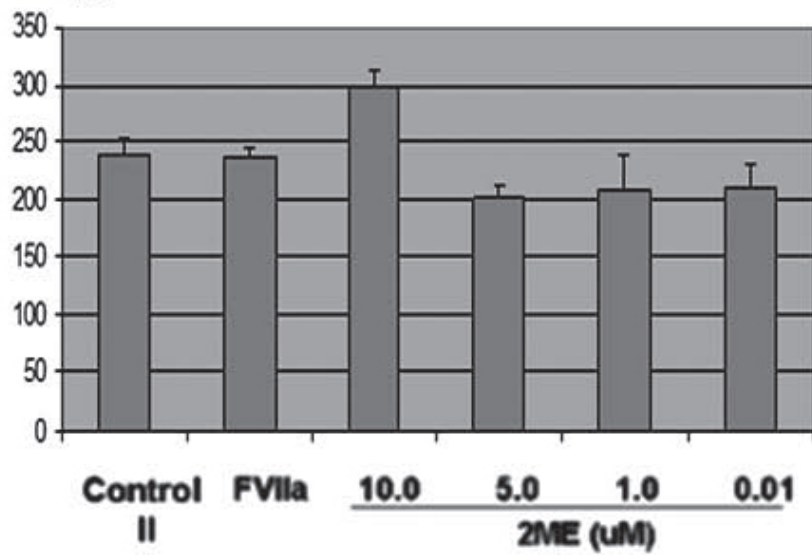

Figure 2: Application of the EA.hy926 angiogenic assay to screen test compounds. (A) Angiogenic Potential Assay: EA.hy926 cells were incubated with CM from breast cancer cells not treated (control) or treated for 12 hours with a compound of known pro-angiogenic potential, FVIIa. Angiogenic potential is represented as the percentage change in the score for cell remodeling in comparison to control. (B) Angiogenic Assay: EA.hy926 cells were incubated with CM (derived from cancer cells treated with a pro-angiogenic cocktail) and the resulting angiogenic score derived from the formula set at $100 \%$ (Control II). FVIIa and stated increasing concentrations of the known anti-angiogenic compound, $2 \mathrm{ME}$, were added at the moment the EA.hy926 cells were plated and the angiogenic score calculated 12 hours later. Values are expressed as percentage of control (control II) from a minimum of three independent experiments. *Statistical significance in respect to each control set at $\mathrm{p}<0.05$. The total numbers of cells do not vary greatly between compounds under analysis or between individual optic fields. (C) demonstrates the change in total cell number in individual optic fields in a representative experiment in the presence of the pro-angiogenic factor, FVII, while (D) represents the same change for the anti-angiogenic agent $2 \mathrm{ME}$. 
migration plays such an integral part in the angiogenic process. For counting purposes, the formula for angiogenesis in vitro or angiogenic potential is shown in figure $1 \mathrm{~B}$. Each cell within the optical field is counted and this number is referred to as the "total number of cells". Each cell that shows sprouting is given a score of 1 point. When two or more prolongations unite and form connected cells, a score of 2 points is awarded to each cell involved in this process. The formation of a polygon is given a single additional value of 3 points. More than one polygon can be present per field, thus three polygons will give a total of nine points to the score given for sprouting and connected cells. These values are calculated as in formula 1, and thus the score for sprouting, connected cells and polygons is divided by the total number of cells. The presence of a complex mesh (luminal structures consisting of walls of two to three cells thick) is given a score of 1 and is added to the total value. This score is added once per optical field. If this complex structure is present and the walls are four or more cells thick, then a score of 2 is awarded. The absence of complex mesh has a score of 0 points. The individual final score derived from the formula is then taken as one value in a total of ten, with the average and standard deviation represented against other treatment conditions. Taking the example of figure $1 \mathrm{~A}$ (hypothetically taking these panels as individual results obtained at the same time point), table III demonstrates the designation of points and the total score for the individual eight panels.

TABLE II

Published models and quantifications methods.

\begin{tabular}{|c|c|c|c|}
\hline Author & Year & Model & Method \\
\hline COURTWRIGHT et al. & 2009 & MEC & Number of branch points \\
\hline FRIEDLI et al. & 2009 & BAE & Tube formation \\
\hline ZHENG et al. & 2009 & MBEC & Tube lenght per $\mathrm{mm}^{2}$ area \\
\hline NIWA et al. & 2009 & DMEC & Area of capillaries \\
\hline XU et al. & 2008 & HUVEC & Tube formation \\
\hline BIAN et al. & 2008 & HUVEC & Tube formation \\
\hline BASU et al. & 2008 & HAEC and HMVEC & $\begin{array}{l}\text { Number of tubes, tube lengths, tube } \\
\text { areas, number of nodal branch points, } \\
\text { and the angiogenic index. }\end{array}$ \\
\hline SMADJA et al. & 2007 & EPC & Endothelial cells networks \\
\hline SAKAI et al. & 2007 & HUVEC & Tube formation \\
\hline PARK et al. & 2007 & HUVEC and HDMEC & Tubular lengths \\
\hline PASCHOALIN et al. & 2007 & HUVEC & Angiogenic structures (closed rings) \\
\hline KONDO et al. & 2007 & KEC & Branching morphogenesis. \\
\hline ALBERT et al. & 2007 & HUVEC & Number of tubes \\
\hline KONG et al. & 2007 & HUVEC & Tubule/capillary length \\
\hline DONG et al. & 2007 & HUVEC & Lengths of tubes \\
\hline PIQUERAS et al. & 2007 & EA hy926 & Number of tubes \\
\hline SECCHIERO et al. & 2007 & HUVEC & $\begin{array}{c}\text { Number of connections among } 3 \text { or more } \\
\text { capillary-like structures and the total length } \\
\text { of tubes }\end{array}$ \\
\hline MOVAFAGH et al. & 2006 & HUVEC & Area of the tube network \\
\hline BIJMAN et al. & 2006 & HUVEC & Number of connections \\
\hline AL-ANI et al. & 2006 & PAEC & Capillary-like tube formation \\
\hline CAO et al. & 2006 & HUVEC & Capillary-like tube structures \\
\hline SUN et al. & 2006 & Human capillary endothelial & Tube formation \\
\hline LAKE et al. & 2006 & HUVEC & $\begin{array}{l}\text { Numerical representation for no real } \\
\text { tubes; some poorly formed tubes; } \\
\text { some formed tubes; network of tubes } \\
\text { both formed and poorly formed; }\end{array}$ \\
\hline
\end{tabular}


TABLE II (Continuation)

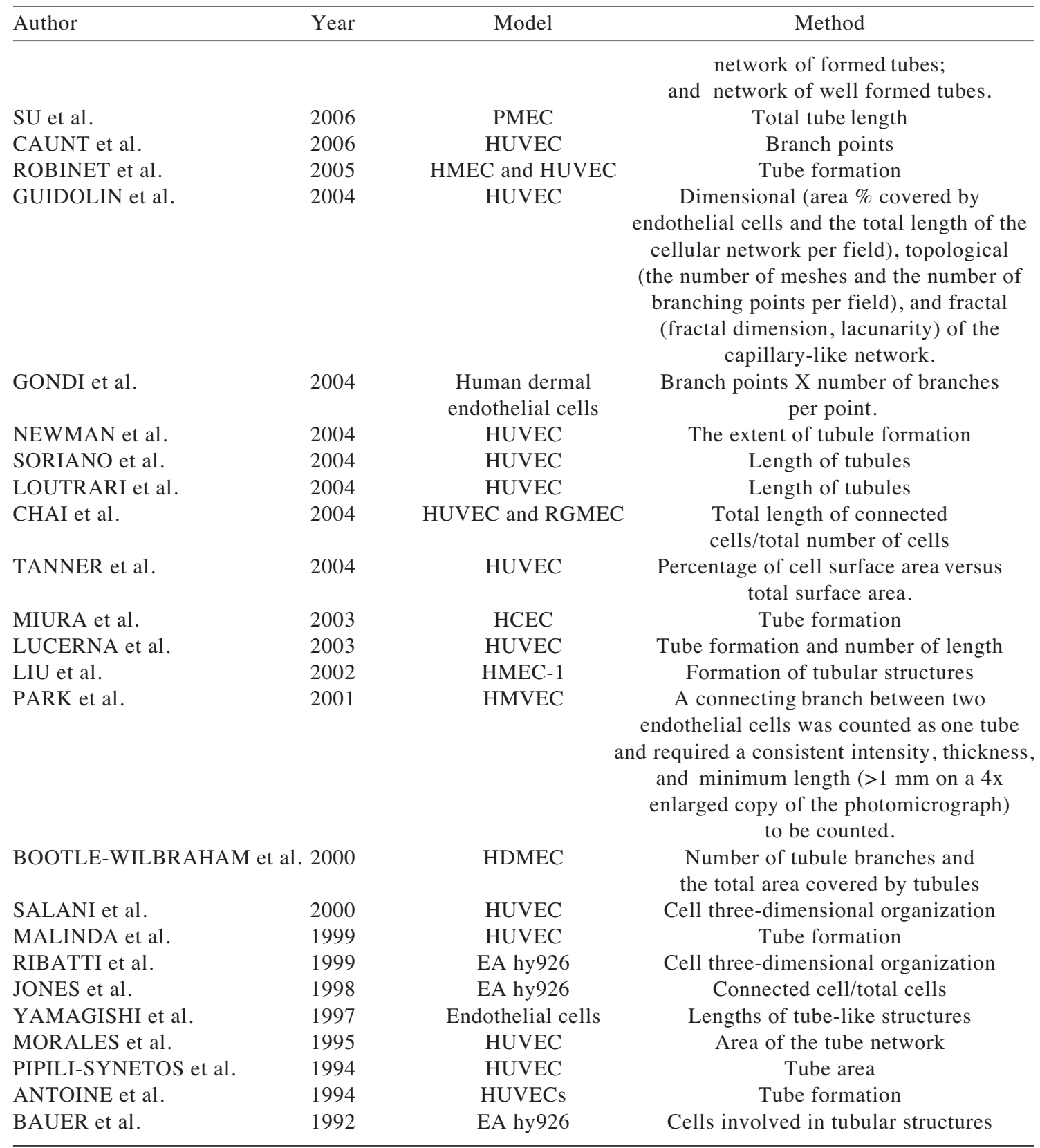

MAE: Myocardial Endothelial cells

BAE: Bovine Aortic Endothelial cells

MBEC: Mouse Brain Endothelial cells

DMEC: Dermal Microendothelial Cells

EPC: Endothelial Progenitor Cells

HUVEC: Human Umbilical Vein Endothelial cells

HDMEC: Human Dermal Microvascular Endothelial Cells

HAEC: Human Aortic Endothelial Cells

HMVEC: Human Microvascular Endothelial Cells

KEC: Kidney Endothelial Cells

PAEC: Porcine Aortic Endothelial Cells

PMEC: Pulmonary Microvascular Endothelial cells

RGMEC: Rat Gastric Microvascular Endothelial Cells

HCEC: Human Colonic Epithelial Cells 
TABLE III

The angiogenic potential for each panel shown in figure 1 .

\begin{tabular}{cccccccc}
\hline Panel & $\begin{array}{c}\text { Total } \\
\text { number of cells }\end{array}$ & $\begin{array}{c}\text { Sprouting } \\
\text { cells }\end{array}$ & $\begin{array}{c}\text { Connected } \\
\text { cells }\end{array}$ & Poligons & \multicolumn{2}{c}{$\begin{array}{c}\text { Complex mesh } \\
<4\end{array}$} & $\begin{array}{c}\text { Angiogenic } \\
\text { Potential }\end{array}$ \\
\hline 1 & 51 & 0 & 0 & 0 & No & No & 0 \\
2 & 40 & 11 & 8 & 0 & No & No & 0.6 \\
3 & 47 & 2 & 22 & 0 & No & No & 0.9 \\
4 & 52 & 10 & 36 & 0 & No & No & 1.5 \\
5 & 50 & 5 & 37 & 3 & No & No & 1.7 \\
6 & 48 & 0 & 47 & 9 & No & No & 2.5 \\
7 & 51 & 0 & 50 & 3 & Si & No & 3.1 \\
8 & 61 & 0 & 61 & 3 & No & Si & 4.2 \\
\hline
\end{tabular}

As an example of how this assay can be applied, figure $2 \mathrm{~A}$ demonstrates the incubation of EA.hy926 cells with CM from breast cancer cells treated for 12 hours with and without (control) a known compound that possesses pro-angiogenic potential, coagulation factor VIIa (FVIIa). As is observed, FVIIa increases angiogenic potential 2-fold in this reproducible assay. Conversely, FVIIa is not pro-angiogenic (no increase is observed over control when applied directly to EA.hy 926 cells, fig. 2B). However, a known anti-angiogenic compound, $2 \mathrm{ME}$, is capable of eliminating angiogenesis in this assay in a concentration dependent manner, when added to the CM (Control II) at the moment of incubation with the EA.hy926 cells. As previously mentioned, these graphs reflect EA.hy926 cell reorganization and not an increase or decrease in cell number, as demonstrated in figure $2 \mathrm{C}$ and $2 \mathrm{D}$. This demonstrates that this assay can numerically differentiate between compounds and concentrations of each compound under investigation. In both figure $2 \mathrm{~A}$ and figure $2 \mathrm{~B}$, angiogenic potential and anti-angiogenic activity respectively, are represented as the percentage change in the score for cell remodeling in the presence of respective controls. However, these results can equally be represented as absolute values of the numerical score derived from the formula.

\section{DISCUSSION}

The use of the EA.hy926 cell line in matrigel is a simple and effective assay to evaluate in vitro angiogenesis. As has been reported before, this assay has the advantage of being reproducible and thus experiments are not dependent on the source of primary tissue from placenta (as with HUVEC) or the difference in response that may come with the genetic variation of each HUVEC sample. Furthermore, the assay is relatively simple, the major cost being the matrigel, cell culture plastic ware, culture medium and FBS. Other important advantages of this assay are the ability to measure both pro- or anti-angiogenic potential and the speed at which the EA.hy926 cells remodel, allowing a rapid answer to whether a compound has a form of angiogenic activity. Generally, the assay can be formed from start to finish in two to three days. However, as with any in vitro assay, drawbacks are present. Despite numerous publications, as shown in table II, no consensus is present on how to interpret and quantify results coming from this assay. The remodelling of the EA.hy926 cell line in the presence of angiogenic factors does not relate directly to processes in in vivo angiogenesis. The interpretation of whether a compound is more or less angiogenic may not reflect absolute angiogenic capability, but only give a measurement of the kinetics of the compound under investigation. 
Furthermore, the assay does not discriminate between a compound that is apoptotic, antiproliferative or in fact anti-angiogenic. In this respect, we commonly perform cell viability and other functional assays on compounds that show anti-angiogenic effects in this assay. Taking into consideration the inevitable interpretations in in vitro assays, the authors believe that this is the best assay available for the rapid screening of possible angiogenic compounds and an extremely useful biological tool to measure angiogenesis in a research laboratory.

Herein, using a cocktail of proangiogenic factors, we have analysed in detail the growth and remodelling of the EA.hy926 cell line in matrigel. We hope that this publication may contribute to both the standardization of the terminology and the quantification of this in vitro assay. After analysing over 2,000 samples, we are confident that the proposed formula will accurately reflect the degree of remodelling observed under the microscope and allow statistical differences in angiogenic potential to be ascertained between two conditions or compounds. The direct visual analysis and assignment of numerical value negates the need for computer analysis and software design present in several published quantitative assays (Guidolin et al., 2004; Lake et al., 2006; Basu et al., 2008). This quantification technique may provide an inexpensive initial screening model for applications in the pharmaceutical industry and as a research tool in the elucidation of angiogenic pathways with the research setting.

\section{ACKNOWLEDGEMENTS}

The authors are grateful to Dr Cora-Jean S. Edgell for the gift of EA.hy926 endothelial cell line.

\section{REFERENCES}

1 AL-ANI B, HEWETT PW, AHMED S, CUDMORE M, FUJISAWA T, AHMAD S, AHMED A (2006) The release of nitric oxide from S-nitrosothiols promotes angiogenesis. PLoS ONE 20: e25

2 ALBERT JM, CAO C, KIM KW, WILLEY CD, GENG
L, XIAO D, WANG H, SANDLER A, JOHNSON DH, COLEVAS AD, LOW J, ROTHENBERG ML, LU B (2007) Inhibition of poly(ADP-ribose) polymerase enhances cell death and improves tumor growth delay in irradiated lung cancer models. Clin Cancer Res 13: 3033-3042

3 ANTOINE N, GREIMERS R, DE ROANNE C, KUSAKA M, HEINEN E, SIMAR LJ, CASTRONOVO V (1994) AGM-1470, a potent angiogenesis inhibitor prevents the entry of normal but not transformed endothelial cells into the G1 phase of the cell cycle. Cancer Res 54: 2073-2076

4 BASU P, GHOSH RN, GROVE LE, KLEI L, BARCHOWSKY A (2008) Angiogenic potential of 3nitro-4-hydroxy benzene arsonic Acid (roxarsone). Environ Health Perspect 116: 520-523

5 BAUER J, MARGOLIS M, SCHREINER C, EDGELL CJ, AZIZKHAN J, LAZAROWSKI E, JULIANO RL (1992) In vitro model of angiogenesis using a human endothelium-derived permanent cell line: contributions of induced gene expression, G-proteins, and integrins. J Cell Physiol 153: 437-449

6 BIAN W, CHEN F, BAI L, ZHANG P, QIN W (2008) Dihydrotanshinone I inhibits angiogenesis both in vitro and in vivo. Acta Biochim Biophys Sin (Shangai) 40: $1-6$

7 BIJMAN MN, VAN NIEUW AMERONGEN GP, LAURENS N, VAN HINSBERGH VW, BOVEN E (2006) Microtubule-targeting agents inhibit angiogenesis at subtoxic concentrations, a process associated with inhibition of Rac 1 and $\mathrm{Cdc} 42$ activity and changes in the endothelial cytoskeleton. Mol Cancer Ther 5: 2348-2357

8 BRAHN E, BANQUERIGO ML, LEE JK, PARK EJ, FOGLER WE, PLUM SM (2008) An angiogenesis inhibitor, 2-methoxyestradiol, involutes rat collageninduced arthritis and suppresses gene expression of synovial vascular endothelial growth factor and basic fibroblast growth factor. J Rheumatol 35: 2119-2128

9 BOOTLE-WILBRAHAM CA, TAZZYMAN S, MARSHALL JM, LEWIS CE (2000) Fibrinogen Efragment inhibits the migration and tubule formation of human dermal microvascular endothelial cells in vitro. Cancer Res 60: 4719-4724

10 CAO C, ALBERT JM, GENG L, IVY PS, SANDLER A, JOHNSON DH, LU B (2006) Vascular endothelial growth factor tyrosine kinase inhibitor AZD2171 and fractionated radiotherapy in mouse models of lung cancer. Cancer Res 66: 11409-11415

11 CAUNT M, HU L, TANG T, BROOKS PC, IBRAHIM S, KARPATKIN S (2006) Growth-regulated oncogene is pivotal in thrombin-induced angiogenesis. Cancer Res 66: 4125-4132

12 CHAI J, JONES MK, TARNAWSKI AS (2004) Serum response factor is a critical requirement for VEGF signaling in endothelial cells and VEGF-induced angiogenesis. FASEB J 18: 1264-1266

13 COURTWRIGHT A, SIAMAKPOUR-REIHANI S, ARBISER JL, BANET N, HILLIARD E, FRIED L, LIVASY C, KETELSEN D, NEPAL DB, PEROU CM, PATTERSON C, KLAUBER-DEMORE N (2009) Secreted frizzle-related protein 2 stimulates angiogenesis via calcineurin/NFAT signaling pathway. Cancer Res 69: 4621-4628

14 DONG YL, REDDY DM, GREEN KE, CHAUHAN MS, WANG HQ, NAGAMANI M, HANKINS GD, YALLAMPALLI C (2007) Calcitonin gene-related peptide (CALCA) is a proangiogenic growth factor in the human placental development. Biol Reprod 76: 892-899 
15 DORRELL MI, AGUILAR E, FRIEDLANDER M (2002) Retinal vascular development is mediated by endothelial filopodia, a preexisting astrocytic template and specific R-cadherin adhesion. Invest Ophthalmol Vis Sci 43: 3500-3510

16 EDGELL CJ, MCDONALD CC, GRAHAM JB (1983) Permanent cell line expressing human factor VIIIrelated antigen established by hybridization. Proc Natl Acad Sci USA 80: 3734-3737

17 EDGELL CJ, HAIZLIP JE, BAGNELL CR, PACKENHAM JP, HARRISON P, WILBOURN B, MADDEN VJ (1990) Endothelium specific WeibelPalade bodies in a continuous human cell line, EA.hy926. In Vitro Cell Dev Biol 26: 1167-1172

18 EMEIS JJ, EDGELL CJ (1988) Fibrinolytic properties of a human endothelial hybrid cell line (Ea.hy 926). Blood 71: 1669-1675

19 ENGEL LW, YOUNG NA, TRALKA TS, LIPPMAN ME, O'BRIEN SJ, JOYCE MJ (1978) Establishment and characterization of three new continuous cell lines derived from human breast carcinomas. Cancer Res 38: 3352-3364

20 EREMEEVA ME, SILVERMAN DJ (1998) Rickettsia rickettsii infection of the EA.hy 926 endothelial cell line: morphological response to infection and evidence for oxidative injury. Microbiology 144: 2037-2048

21 FOLKMAN J, SHING Y (1992) Angiogenesis. J Biol Chem 267: 10931-10934

22 FRIEDLI A, FISCHER E, NOVAK-HOFER I, COHRS S, BALLMER-HOFER K, SCHUBIGER PA, SCHIBLI R, GRUNBERG J (2009) The soluble form of the cancer-associated $\mathrm{L} 1$ cell adhesion molecule is a proangiogenic factor. Int J Biochem Cell Biol 41: 15721580

23 GERSTNER ER, DUDA DG, DI TOMASO E, SORENSEN G, JAIN RK, BATCHELOR TT (2007) Antiangiogenic agents for the treatment of glioblastoma. Expert Opin Investig Drugs 16: 18951908

24 GONDI CS, LAKKA SS, DINH DH, OLIVERO WC, GUJRATI M, RAO JS (2004) Downregulation of uPA, UPAR and MMP-9 using small, interfering, hairpin RNA (siRNA) inhibits glioma cell invasion, angiogenesis and tumor growth. Neuron Glia Biol 1: 165-176

25 GOODWIN AM (2007) In vitro assays of angiogenesis for assessment of angiogenic and anti-angiogenic agents. Microvasc Res 74: 172-183

26 GUIDOLIN D, VACCA A, NUSSDORFER G, RIBATTI D (2004) A new image analysis method based on topological and fractal parameters to evaluate the angiostatic activity of docetaxel by using the Matrigel assay in vitro. Microvasc Res 67: 117-124

27 JONES MK, SARFEH IJ, TARNAWSKI AS (1998) Induction of in vitro angiogenesis in the endothelialderived cell Line, EA hy926, by Ethanol Is Mediated through PKC and MAPK. Biochem Biophys Res Commun 249: 118-123

28 KONDO S, SCHEEF EA, SHEIBANI N, SORENSON CM (2007) PECAM-1 isoform-specific regulation of kidney endothelial cell migration and capillary morphogenesis. Am J Physiol Cell Physiol 292: C2070C2083

29 KONG D, LI Y, WANG Z, BANERJEE S, SARKAR FH (2007) Inhibition of angiogenesis and invasion by 3,3'-diindolylmethane is mediated by the nuclear factor-kappaB downstream target genes MMP-9 and uPA that regulated bioavailability of vascular endothelial growth factor in prostate cancer. Cancer Res 67: 3310-3319
30 LAKE AC, VASSY R, DI BENEDETTO M, LAVIGNE D, LE VISAGE C, PERRET GY, LETOURNEUR D (2006) Low molecular weight fucoidan increases VEGF165-induced endothelial cell migration by enhancing VEGF165 binding to VEGFR2 and NRP1. J Biol Chem 281: 37844-37852

31 LIU J, WANG XB, PARK DS, LISANTI MP (2002) Caveolin-1 expression enhances endothelial capillary tubule formation. J Biol Chem 277: 10661-10668

32 LOUTRARI $\mathrm{H}$, HATZIAPOSTOLOU $\mathrm{M}$, SKOURIDOU V, PAPADIMITRIOU E, ROUSSOS C, KOLISIS FN, PAPAPETROPOULOS A (2004) Perillyl Alcohol Is an Angiogenesis Inhibitor. J Pharmacol Exp Ther 311: 568-575

33 LUCERNA M, MECHTCHERIAKOVA D, KADL A, SCHABBAUER G, SCHÄFER R, GRUBER F, KOSHELNICK Y, MÜLLER HD, ISSBRÜCKER K, CLAUSS M, BINDER BR, HOFER E (2003) NAB2, a corepressor of EGR-1, inhibits vascular endothelial growth factor-mediated gene induction and angiogenic responses of endothelial cells. J Biol Chem 278: 11433-11440

34 MABJEESH NJ, ESCUIN D, LAVALLEE TM, PRIBLUDA VS, SWARTZ GM, JOHNSON MS, WILLARD MT, ZHONG H, SIMONS JW, GIANNAKAKOU P (2003) 2ME2 inhibits tumor growth and angiogenesis by disrupting microtubules and dysregulating HIF. Cancer Cell 3: 363-375

35 MALINDA KM, NOMIZU M, CHUNG M, DELGADO M, KURATOMI Y, YAMADA Y, KLEINMAN HK, PONCE ML (1999) Identification of laminin alpha1 and beta 1 chain peptides active for endothelial cell adhesion, tube formation, and aortic sprouting. FASEB J 13: 53-62

36 MIURA S, MATSUO Y, SAKU K (2003) Transactivation of KDR/Flk-1 by the B2 receptor induces tube formation in human coronary endothelial cells. Hypertension 41: 1118-1123

37 MORALES DE, McGOWAN KA, GRANT DS, MAHESHWARI S, BHARTIYA D, CID MC, KLEINMAN HK SCHNAPER HW (1995) Estrogen promotes angiogenic activity in human umbilical vein endothelial cells in vitro and in a murine model. Circulation 91: 755-763

38 MOVAFAGH S, HOBSON JP, SPIEGEL S, KLEINMAN HK, ZUKOWSKA Z (2006) Neuropeptide $Y$ induces migration, proliferation, and tube formation of endothelial cells bimodally via Y1, Y2, and Y5 receptors. FASEB J 20: 1924-1926

39 NEWMAN SP, LEESE MP, PUROHIT A, JAMES DR RENNIE CE, POTTER BV, REED MJ (2004) Inhibition of in vitro angiogenesis by 2-methoxy- and 2-ethyl-estrogen sulfamates. Int J Cancer 109: 533-540

40 NIWA S, GRAF C, BORNANCIN F (2009) Ceramide kinase deficiency impairs microendothelial cell angiogenesis in vitro. Microvasc Res 77: 389-393

41 PARK MJ, KWAK HJ, LEE HC, YOO DH, PARK IC, KIM MS, LEE SH, RHEE CH, HONG SI (2007) Nerve growth factor induces endothelial cell invasion and cord formation by promoting matrix metalloproteinase2 expression through the phosphatidylinositol 3Kinase/Akt signaling pathway and AP-2 transcription factor. J Biol Chem 282: 30485-30496

42 PARK CC, MOREL JC, AMIN MA, CONNORS MA, HARLOW LA, KOCH AE (2001) Evidence of IL-18 as a novel angiogenic mediator. J Immunol 167: 16441653

43 PASCHOALIN T, CARMONA AK, RODRIGUES EG, OLIVEIRA V, MONTEIRO HP, JULIANO MA, JULIANO L, TRAVASSOS LR (2007) 
Characterization of thimet oligopeptidase and neurolysin activities in B16F10-Nex2 tumor cells and their involvement in angiogenesis and tumor growth. Mol Cancer 9: 44

44 PIPILI-SYNETOS E, SAKKOULA E, HARALABOPOULOS G, ANDRIOPOULOU P, PERISTERIS P, MARAGOUDAKIS ME (1994) Evidence that nitric oxide is an endogenous antiangiogenic mediator. Br J Pharmacol 111: 894-902

45 PIQUERAS L, REYNOLDS AR, HODIVALA-DILKE KM, ALFRANCA A, REDONDO JM, HATAE T, TANABE T, WARNER TD, BISHOP-BAILEY D (2007) Activation of PPARbeta/delta induces endothelial cell proliferation and angiogenesis. Arterioscler Thromb Vasc Biol 27: 63-69

46 PLUDA JM (1997) Tumor-associated angiogenesis: mechanisms, clinical implications, and therapeutic strategies. Semin Oncol 24: 203-218

47 RIBATTI D, PRESTA M, VACCA A, RIA R, GIULIANI R, DELL'ERA P, NICO B, RONCALI L, DAMMACCO F (1999) Human erythropoietin induces a pro-angiogenic phenotype in cultured endothelial cells and stimulates neovascularization in vivo. Blood 93: 2627-2636

48 RICKER JL, CHEN Z, YANG XP, PRIBLUDA VS, SWARTZ GM, VAN WAES C (2004) 2methoxyestradiol inhibits hypoxia-inducible factor lalpha, tumor growth, and angiogenesis and augments paclitaxel efficacy in head and neck squamous cell carcinoma. Clin Cancer Res 10: 8665-8673

49 ROBINET A, FAHEM A, CAUCHARD JH, HUET E, VINCENT L, LORIMIER S, ANTONICELLI F, SORIA C, CREPIN M, HORNEBECK W, BELLON G (2005) Elastin-derived peptides enhance angiogenesis by promoting endothelial cell migration and tubulogenesis through upregulation of MT1-MMP. J Cell Sci 118: 343-356

50 SAIJONMAA O, NYMAN T, HOHENTHAL U, FYHRQUIST F (1991) Endothelin-1 is expressed and released by a human endothelial hybrid cell line (EA.hy 926). Biochem Biophys Res Commun 181: 529-536

51 SAKAI T, BALASUBRAMANIAN K, MAITI S, HALDER JB, SCHROIT AJ (2007) Plasmin-cleaved $\square \leq$-2-glycoprotein 1 is an inhibitor of angiogenesis. Am J Pathol 171: 1659-1669

52 SALANI D, TARABOLETTI G, ROSANÒ L, DI CASTRO V, BORSOTTI P, GIAVAZZI R, BAGNATO A (2000) Endothelin-1 induces an angiogenic phenotype in cultured endothelial cells and stimulates neovascularization in vivo. Am J Pathol 157: 1703-1711

53 SECCHIERO P, CORALLINI F, GONELLI A, DELL'EVA R, VITALE M, CAPITANI S, ALBINI A, ZAULI G (2007) Antiangiogenic activity of the MDM2 antagonist nutlin-3. Circ Res 100: 61-69
54 SMADJA DM, BIECHE I, HELLEY D, LAURENDEAU I, SIMONIN G, MULLER L, AIACH M, GAUSSEM P (2007) Increased VEGFR2 expression during human late endothelial progenitor cells expansion enhances in vitro angiogenesis with upregulation of integrin _6. J Cell Mol Med 11: 11491161

55 SORIANO JV, LIU N, GAO Y, YAO ZJ, ISHIBASHI T, UNDERHILL C, BURKE TR Jr, BOTTARO DP (2004) Inhibition of angiogenesis by growth factor receptor bound protein 2-Src homology 2 domain binding antagonists. Mol Cancer Ther 3: 1289-1299

56 SU Y, CUI Z, LI Z, BLOCK ER (2006) Calpain-2 regulation of VEGF-mediated angiogenesis. FASEB $J$ 20: 1443-1451

57 SUGGS JE, MADDEN MC, FRIEDMAN M, EDGELL CJ (1986) Prostacyclin expression by a continuous human cell line derived from vascular endothelium. Blood 68: 825-829

58 SUN W, LEE TS, ZHU M, GU C, WANG Y, ZHU Y, SHYY JY (2006) Statins activate AMP-activated protein kinase in vitro and in vivo. Circulation 114: 2655-2662

59 TANNER JE, FORTÈ A, PANCHAL C (2004) Nucleosomes bind fibroblast growth factor-2 for increased angiogenesis in vitro and in vivo. Mol Cancer Res 2: 281-288

60 THORNHILL MH, LI J, HASKARD DO (1993) Leucocyte endothelial cell adhesion: a study comparing human umbilical vein endothelial cells and the endothelial cell line EA-hy-926. Scand J Immunol 38: 279-286

61 VAN OOST BA, EDGELL CJ, HAY CW, MACGILLIVRAY RT (1986) Isolation of a human von Willebrand factor cDNA from the hybrid endothelial cell line EA.hy926. Biochem Cell Biol 64: 699-705

62 XU H, CZERWINSKI P, HORTMANN M, SOHN HY, FÖRSTERMANN U, LI H (2008) Protein kinase C alpha promotes angiogenic activity of human endothelial cells via induction of vascular endothelial growth factor. Cardiovasc Res 78: 349-355

63 YAMAGISHI S, YONEKURA $\mathrm{H}$, YAMAMOTO Y, KATSUNO K, SATO F, MITA I, OOKA H, SATOZAWA N, KAWAKAMI T, NOMURA M, YAMAMOTO H (1997) Advanced glycation end products-driven angiogenesis in vitro. Induction of the growth and tube formation of human microvascular endothelial cells through autocrine vascular endothelial growth factor. J Biol Chem 272: 8723-8730

64 ZHENG X, JIANG F, KATAKOWSKI M, ZHANG ZG, LU QE, CHOPP M (2009) ADAM17 promotes breast cancer cell malignant phenotype through EGFRPI3K-AKT activation. Cancer Biol Ther 8: 1141-1150 
